\author{
Pawel Żukowski \\ Wyższa Szkoła Biznesu \\ National-Louis University w Nowym Sączu
}

\title{
Podstawy budowy modelu dynamiki systemu zarządzania oraz jego symulacja w organizacji gospodarczej (na podstawie metodologii dynamiki systemów J.W. Forrestera)
}

\section{Rozważania o myśleniu systemowym}

Podstawą konstrukcji modelu dynamiki systemu zarządzania organizacją gospodarczą i jego symulacji jest teoria i metodologia dynamiki systemów opracowana przez Jaya W. Forrestera, co jest logiczną konsekwencją zastosowania w badaniach i opracowaniu myślenia systemowego (Forrester 1961; 1968; 1978; 1990). Myślenie systemowe zakłada, że nie można zrozumieć jakiejś większej całości, badając jej elementy składowe w oderwaniu od funkcjonowania całości obiektu (rzeczy, zjawiska, procesu), gdyż wówczas mogą się one zachowywać inaczej niż w rzeczywistości jako składniki tej całości. Myślenie systemowe jest sztuką widzenia całości, z wyeksponowaniem interakcji (zależności i oddziaływania) jej elementów składowych ze sprzężeniami zwrotnymi, a nie rozpoznawaniem pojedynczych składników w oderwaniu od (co też daje myśleniu niepowtarzalny charakter). Funkcjonowanie całości to ciąg zdarzeń niekiedy bardzo odległych od siebie w czasie i przestrzeni, przy czym związki pomiędzy elementami systemu nie zawsze są jasne i proste, często są też niewidoczne dla badacza. Jednak istnieją i mogą wywierać poważny wpływ na cały system. Myślenie systemowe bazuje również na twierdzeniu, że rzeczywistość nie jest linearna, lecz wielokierunkowa, złożona z elementów i różnorodnych zależności także w postaci pętli sprzężeń zwrotnych. Sprzężenia zwrotne w systemie powodują, że skutek jego zachowania jest jednocześnie przyczyną tego zachowania. Problem polega tylko na naszej percepcji systemu, przyzwyczajeni jesteśmy bowiem do linearnego widzenia świata, a tymczasem w zachowaniu systemu najważniejsze jest zaobserwowanie sprzężeń zwrotnych oraz ich pętli, a także jego historii (którą one opowiadają). Dzięki temu można zrozumieć, w jaki sposób struktura wpływa na zachowanie systemu (Forrester 1968; Richardson 1991; Śliwa 2001).

Sprzężenia zwrotne wskazują, że problemy w systemie tworzone są przez sam system. Widzenie wzajemnych wielokierunkowych relacji w systemie prowadzi do stwierdzenia, że każdy wpływ (oddziaływanie) jest zarówno przyczyną, jak i skutkiem, ponieważ system działa na zasadzie sprzężenia zwrotnego. Fakt istnienia pętli sprzężeń zwrotnych powoduje to, że ten sam czynnik jest jednocześnie przyczyną i skutkiem, co jest jednym z aksjomatów myślenia systemowego. Myślenie to odrzuca twierdzenie, że zawsze istnieje jakaś jedna przyczyna bądź jednostka lub inny czynnik odpowiedzialny (sprawczy) za powstały problem w systemie, gdyż problemy są generowane (tworzone) przez sam system, jego strukturę (elementy, istniejące zależności, relacje w postaci sprzężenia zwrotnego). Tylko odkrycie i rozpoznanie struktury 
(która dyktuje przecież zachowanie systemu), ze zrozumieniem jej źródła, umożliwia efektywne rozpoczęcie jej zmiany i rozwiązanie problemu(-ów) w systemie (Forrester 1961; Forrester 1971; Wagner 1975; Żukowski 2011).

Myślenie systemowe daje możliwość badania i analizowania struktur leżących u podstaw skomplikowanych sytuacji i rozpoznawania zmian, których konsekwencje powodują powstanie problemów. Jednocześnie uczy ono, że nieraz najbardziej oczywiste rozwiązania nie dają spodziewanych efektów, a w długim okresie ich skutki mogą być zupełnie inne od zamierzonych, ponieważ działania i sposoby rozwiązywania problemów, które wydają się nam oczywiste, $\mathrm{z}$ reguły opierają się tylko na jednostronnym widzeniu powstałego problemu w oderwaniu od pozostałych zagadnień i uwarunkowań tworzących w rzeczywistości problem w systemie. Dzięki myśleniu systemowemu dowiadujemy się również, iż czasem niepozorne, ale dobrze ukierunkowane działania mogą dać trwałe polepszenie sytuacji oraz właściwe rozwiązanie problemu, gdyż ich podstawą jest znajomość istniejących w systemie powiązań i interakcji oraz rozumienie ich znaczenia dla zachowania się systemu. Działania takie nazywane są wzmocnieniem. Zmiany opierające się na efekcie wzmocnienia nie są często oczywiste i nie ma prostych reguł, które umożliwiałyby nam znalezienie zmian skutkujących silnym wzmocnieniem. Kluczowym zagadnieniem jest tu umiejętność dostrzegania struktur, oddziaływania elementów i ich powiązań, a nie pojedynczych zdarzeń oraz myślenie w kategoriach procesów zmian zamiast koncentracji uwagi na skutkach i przyczynach.

\section{Scalanie myślenia systemowego z modelami myślowymi}

Praktyka myślenia efektywnego uczy, że dla zwiększenia siły myślenia systemowego konieczna jest jego integracja z naszymi modelami myślowymi rozumianymi jako obrazy, założenia myślowe i historie tkwiące w naszym umyśle, za pomocą których interpretujemy i oceniamy samych siebie, innych ludzi, instytucje, otoczenie i każdy aspekt rzeczywistości. Modele myślowe zazwyczaj są przyjmowane milcząco, często są nietestowane ani nie badane, istnieją i funkcjonują poniżej poziomu naszej świadomości i chociaż z reguły są dla nas niewidoczne, to jednak determinują to, co i jak postrzegamy, wpływają na sposób naszego rozumowania i wnioskowania, a w konsekwencji kształtują nasze działania. Silnie wpływają na to, co robimy, gdyż determinują to, co widzimy, jak postrzegamy i interpretujemy otaczającą nas rzeczywistość. Modele myślowe odnoszą się zarówno do długoterminowej pamięci ludzkiej, jak i krótkookresowych postrzeżeń, budowanych w toku codziennych procesów rozumowania.

Menedżerowie muszą nauczyć się ujawniać, badać i analizować swoje modele myślowe, dociekać swoich i cudzych sposobów myślenia, w dyskusjach otwarcie wymieniać poglądy i uzyskiwać wiedzę o założeniach myślowych przyjmowanych przez innych ludzi, uwzględniać modele myślowe rozmówców, słuchać, co faktycznie oni mówią, a nie tylko to, co od nich chcieliby usłyszeć, przedstawiać otwarcie dominujące założenia, dostrzegać nieuchronność stronniczości we własnych sposobach myślenia, tolerować różne interpretacje biegu zdarzeń przez innych, a nie widzieć tylko własne interpretacje, osłabiać własne nastawienia obronne, ciągle doskonalić swoje modele myślowe. Modele myślowe menedżera nie mogą jednak wykazywać takich niedostatków, jak skupianie się na zmiennych najbardziej widocznych, zamiast na tych, które gwarantują silne wzmocnienia w systemie, pomijanie kluczowych relacji (pętli) sprzężeń zwrotnych czy mylne oceny opóźnień czasowych w systemie, co wynika z niedostatków (przestarzałości) w modelach myślowych. Wyniki współczesnych badań dowodzą, że większość używanych przez menedżerów modeli myślowych wykazuje stałe niedostatki, w szczególności są niekompletne i w dodatku chronicznie niesystemowe. J. Sterman z MIT (Massachusetts Institute of Technology) eksperymentalnie stwierdził, że menedżerowie nie 
widzą (nie mają rozeznania) albo nie biorą pod uwagę przy podejmowaniu istotnych decyzji kryterium istniejącego opóźnienia czasowego w systemie (wzmacniającego sprzężenia zwrotnego) (Stern 1987). W związku z tym bardzo dużego znaczenia nabiera praca z modelami myślowymi w celu ich ujawniania i doskonalenia, gdzie centralną rolę odgrywają umiejętności myślenia refleksyjnego i dociekania. Umiejętności i zdolności myślenia refleksyjnego prowadzą do spowalniania procesów myślowych w celu uzyskania samowiedzy na temat tego, jak w naszym umyśle formujemy modele myślowe, a zdolności dociekania polegają na prowadzeniu rozmów i dyskusji, w toku których otwarcie wymieniamy poglądy i uzyskujemy wiedzę o przekonaniach przyjmowanych przez innych ludzi w ich modelach myślowych, co umożliwia ujawnianie i wyjaśnianie (ocenę) ukrytych w nich założeń myślowych. Jeżeli menedżer nie ma ugruntowanego naukowo sposobu rozumienia modeli myślowych i ich roli w myśleniu systemowym, to bez eksperymentowania z nowymi sposobami myślenia nie usprawni swoich modeli myślowych.

Modele myślowe koncentrują się na wyjaśnianiu ukrytych przekonań i założeń tkwiących w naszym umyśle, natomiast myślenie systemowe skupia się na tym, jak zrestrukturyzować założenia myślowe, aby można było odkryć przyczyny istotnych problemów. Te dwie dyscypliny powinny współdziałać ze sobą w sposób naturalny i wzajemnie uzupełniać się. Końcowym efektem integrowania myślenia systemowego i modeli myślowych jest nie tylko udoskonalenie samych modeli (tego, co myślimy), ale także zmiana sposobu myślenia menedżera - przejście od modeli myślowych zdominowanych przez linearne i krótkoterminowe postrzeganie wydarzeń do modeli myślowych, które uwzględniają wielokierunkowość i długofalowe procesy zmian oraz struktury powodujące te zmiany; nie mamy tu prostych odpowiedzi na skomplikowane pytania. Głęboko zakorzenione modele myślowe w tradycji, często przestarzałe, mogą uniemożliwiać wprowadzenie zmian wynikających z efektywnego myślenia systemowego.

W myśleniu systemowym poglądy, przeświadczenia czy nowe koncepcje są bezpośrednio konfrontowane z modelami myślowymi menedżera. Fakt ten zawęża pole widzenia rzeczywistości przez menedżera, co wynika z ograniczeń jego modeli myślowych (starych założen, wypróbowanych sposobów myślenia) i w związku z tym zmniejsza zarówno siłę, jak i wyniki myślenia systemowego. Dlatego ujawnianie, testowanie, unowocześnianie i ciągłe doskonalenie modeli myślowych menedżerów i ich integracja z myśleniem systemowym ma znaczenie fundamentalne (przełomowe) w usprawnianiu i stosowaniu w praktyce efektywnego myślenia systemowego (Argyris 1982; 1985; Checkland 1981; Sterman 1987).

Liczne badania wskazują też, że doświadczeni menedżerowie i liderzy w myśleniu systemowym i racjonalnym w znacznej mierze polegają również na intuicji. Skomplikowane problemy rozwiązują oni w intuicyjny sposób, którego nie potrafią ani opisać, ani wyjaśnić w kategoriach logiki linearnej (bazują nie tylko na racjonalnych przesłankach) (Agor 1984). Myślenie systemowe może właśnie stanowić klucz do zharmonizowania i integracji racjonalizmu (rozsądku) $\mathrm{i}$ intuicji. Intuicja bowiem unika pułapek myślenia linearnego, z jego akceptowaniem przyczyn i skutków, pozostających blisko siebie w czasie i przestrzeni, podpowiadając, że one nie są ściśle związane ani w czasie, ani w przestrzeni, i że krótkoterminowe racjonalne rozwiązania opierające się na konkretnych, łatwo mierzalnych wielkościach i wskaźnikach osiągnięć mogą maskować głębsze problemy i prowadzić długookresowo do pogarszania się sytuacji.

Zaznaczmy, że racjonalizm i intuicja nie są przeciwieństwem, ich interakcje dają synergię charakteryzującą właśnie wszystkich wielkich myślicieli. A. Einstein wyznał kiedyś, że odkrył zasadę względności dzięki wyobrażeniu sobie podróży na promieniu światła. Swoją więc błyskotliwą intuicję i modele myślowe potrafił połączyć z racjonalnością i ścisłą analizą (Mac Donald 1992, Senge 1985). 


\section{Dynamika systemów}

W dynamice systemów rozpoznawana całość nazywana jest właśnie systemem. System rozumieć należy jako pewną, postrzegalną całość, której elementy są wzajemnie powiązane, stale ze sobą znajdują się w interakcjach (oddziaływaniach) i działają łącznie na rzecz wspólnego celu (Forrester 1978; Roberts 1964; Sange 2008; Żukowski 2006; Żukowski 2011).

Definicja systemu w określonym stopniu opisuje też przedmiot badań metody dynamiki systemów, gdyż tę dynamikę cechuje całościowy pogląd na badany problem, a struktura i granice systemu są definiowane przez projektanta. System jest wytworem naszego postrzegania, naszej wiedzy o nim i jego funkcjonowania. Wiedza ta pozwala na prawidłową konstrukcję modelu dynamiki systemu oraz zrozumienie jego zachowania. Składniki systemów są ze sobą połączone niewidocznymi strukturami oddziaływań, które są wzajemnie od siebie zależne, chociaż zanim działania te wpłyną na zachowanie się systemu, może upłynąć dużo czasu; powiązania te funkcjonują również pomiędzy elementami, które są od siebie bardzo odległe, nie tylko w czasie, ale i w przestrzeni (Forrester 1961; Roberts 1964; Tarajkowski 2008).

Dynamika systemów jest nie tylko metodologią, lecz także metodą, która opiera się na twierdzeniu, że za zmiany i powstawanie problemów w systemie odpowiedzialna jest jego struktura determinująca zachowanie. Przyczyną powstania problemu jest cały system, wszystkie jego obszary, nie należy zatem upatrywać źródła problemu tylko w jednym lub kilku jego elementach. Metoda dynamiki systemów odchodzi od linearnego twierdzenia: przyczyna problem - skutek. Myśląc systemowo, należy analizować system całościowo, ponieważ to właśnie jego struktura generuje zachowanie się systemu prowadzące do powstania problemu. Stosując tę metodę, należy odejść od poszukiwania przyczyn problemów blisko miejsca ich wystąpienia i zaprzestać stosowania rozwiązań maskujących tylko skutki problemu, ponieważ jego przyczynę możemy znaleźć w bardzo odległej i pozornie niezwiązanej z problemem części systemu, a wnioski niejednokrotnie mogą być zaskakujące. Metoda dynamiki systemów zamiast poszukiwać przyczyn problemu, skupia się na odkrywaniu struktury (elementów i sprzężeń zwrotnych) i zachowaniu się systemu. Znajomość zarówno struktury, jak i zachowania się systemu daje możliwość skutecznego rozwiązywania problemów zamiast rozwiązań i działań, których efekty będą tylko chwilowe, a po pewnym czasie mogą spowodować, że problem powróci i będzie większy niż poprzednio. Dynamika systemów jest dziedziną łączącą wiedzę opisową o świecie z opisami, w jaki sposób struktury sprzężeń zwrotnych wpływają na wszystkie zmiany w systemach w czasie, z uwzględnieniem także znaczenia ograniczeń mających swe miejsce w modelach myślowych. Dzięki rozwojowi techniki komputerowej i ciągłemu zwiększaniu jej mocy obliczeniowej można rozwiązywać coraz bardziej skomplikowane problemy w systemie. Dynamika systemów prowadzi do zrozumienia struktur generujących niepożądane zachowania systemów i pozwala na znalezienie rozwiązań prowadzących do ich zmiany i doskonalenia (Forrester 1971; Forrester 1990; Penc 2000; Rue, Holland 1986).

Zachowania wszystkich systemów przebiegają według pewnych wspólnych wzorców, tzw. archetypów systemowych, które ujawniają się po poznaniu struktury systemu. Wszystkie archetypy systemowe są zbudowane ze sprzężeń zwrotnych wzmacniających (dodatnich), pętli regulujących (sprzężeń zwrotnych ujemnych) oraz opóźnień. Wskazują one, w jaki sposób sami tworzymy naszą rzeczywistość (Sange 2008; Śliwa 2001). Dlatego bardzo ważne jest dobre zrozumienie i poznanie struktury systemu, poddanego badaniu relacji, które występują pomiędzy jego elementami składowymi, oraz charakteru i działania tych powiązań (sprzężeń zwrotnych). Ponieważ dynamika systemów opiera się na koncepcji sprzężeń zwrotnych, w których wszystkie zdarzenia zachodzą równocześnie, pozwala ona poznać słabe strony systemu, zdarzenia i błędy mające miejsce w przeszłości, a także ich wpływ na teraźniejsze zachowanie się 
systemu. Pozwala to stwierdzić, że dzisiejsze zachowanie się systemu pozwoli nam z dużym prawdopodobieństwem przewidywać jego zachowanie się w przyszłości.

Narzędzia i techniki stosowane w myśleniu systemowym, jak również metoda dynamiki systemów, wywodzą się z koncepcji sprzężenia zwrotnego i z powodzeniem są stosowane do badań i symulacji systemów przedsiębiorstw, korporacji, banków i innych instytucji, systemów ekonomicznych oraz politycznych czy systemów miast (metropolii). Myślenie systemowe opiera się bowiem na ogólnych zasadach dotyczących bardzo różnorodnych i odległych od siebie dziedzin i dyscyplin naukowych, takich jak: biologia, socjologia, fizyka, inżynieria czy zarządzanie; zasady te dają się łatwo adaptować z jednej dziedziny do drugiej. Sprawia to również, że i metoda dynamiki systemów, stosując konsekwentnie myślenie systemowe, jest uniwersalnym narzędziem badawczym, które przy wykorzystaniu tych samych technik może być praktycznie stosowane w każdej dziedzinie nauki, gospodarki i życia społecznego (Forrester 1971; Roberts 1985; Żukowski 2011).

W stosowaniu metody dynamiki systemów konieczne jest zrozumienie złożoności dynamicznej problemów i różnych konsekwencji działań w czasie i przestrzeni, niezbędne jest również dostrzeganie opóźnień pomiędzy działaniami a ich skutkami (efektami) (Śliwa 2001; Tarajkowski 2008). Niedostrzeganie takich opóźnień może powodować nasilanie działań lub ich zaniechanie, co może sprawić, że konsekwencje działań będą zupełnie odmienne od oczekiwanych. Stosując metodę dynamiki systemów, powinniśmy jak najdokładniej poznać badany system oraz wzajemne relacje łączące jego elementy, ponieważ część z tych relacji leży u podstaw tworzących się w systemie problemów i trudności; pozwala to uzyskać nowy pogląd na sposób rozwiązania problemu. Właśnie zmiana sposobu myślenia jest istotą dynamiki systemów oraz myślenia systemowego, powinniśmy widzieć wzajemne wielokierunkowe relacje, a właściwie pętle sprzężeń zwrotnych, a nie linearne łańcuchy przyczynowo-skutkowe oraz całe procesy zmian zachodzących w badanym systemie, zamiast skupiania uwagi na jednym elemencie systemu jako podstawowej przyczynie powstałego problemu.

Sprzężenia zwrotne decydują o zachowaniu się systemu; istnieją wzorce zachowań systemów opierających się na tych sprzężeniach. Typowym przykładem zachowania się systemu opierającego się na dodatnim sprzężeniu zwrotnym (wzmocnieniu) są oszczędności na procent składany - im dłużej oszczędzamy, tym większy kapitał i kwota będąca odsetkami. Takie zachowanie nazywamy wzrostem wykładniczym. Drugim przykładem zachowania się systemu, którego podstawą jest sprzężenie zwrotne dodatnie jest sprzężenie złożone z dwóch ujemnych powiązań, dodatniego sprzężenia zwrotnego zbieżnego i dodatniego sprzężenia zwrotnego rozbieżnego. Przykładem takiego zachowania może być zależność wysokości pensji pracownika magazynu od liczby pomyłek przy wydawaniu towaru, im mniej pomyłek tym pensja wyższa, im pensja wyższa, tym bardziej pracownik będzie się starał jak najmniej popełniać błędów. Regulujące sprzężenia zwrotne hamują wpływ wzmacniających sprzężeń w strukturze problemu oraz odpowiadają za zachowania zmierzające do celu. Zachowania bazujące na pętli równoważącego sprzężenia zwrotnego, to zachowanie oscylacyjne, w którym badana wielkość (jej wartość) wraz z upływem czasu waha się raz w dół, raz w górę, zachowania bazujące na dążeniu do celu, gdzie system zmierza do tego, żeby badana wielkość osiągnęła pożądany stan (wartości), oraz zachowania ograniczające wzrost, czyli takie, w których nadmierny wzrost jakiejś wielkości jest ograniczany przez działanie struktury całego systemu. Wzory zachowania się systemów opierające się na sprzężeniach zwrotnych zarówno sterujących - wzmacniających (dodatnich), jak i regulujących (ujemnych), można zastosować do badania dowolnego systemu, gdyż różne systemy mogą wykazywać, i często wykazują, takie same zachowania, pomimo zupełnie różnego charakteru problemów w nich występujących. Systemowa struktura problemów 
związana jest również z dynamicznymi właściwościami problemów, ich zmiennością w czasie i złożonymi powiązaniami pomiędzy elementami struktury systemu. Dzięki znajomości procesu kształtowania się problemu można zanalizować jego wewnętrzną strukturę. Myślenie systemowe zmusza do badania rozwoju problemu pod kątem występujących w nich zmiennych, ich struktury oraz sprzężeń zwrotnych. Jedynym możliwym trwałym rozwiązaniem problemu o dynamicznej złożoności jest zmiana jego struktury, ponieważ struktura i dynamika problemu są nieodłączne, nie można poznać i zrozumieć powstania problemu bądź zmiany bez poznania i zrozumienia jego struktury i oddziaływania elementów składowych (Forrester 1968; Penc 2000; Porter 1985; Roberts 1964).

Stosując metodę dynamiki systemów w rozwiązywaniu dowolnego problemu, należy zidentyfikować problem oraz zdefiniować podstawowe pojęcia dotyczące zarówno problemu, jak i systemu, w którym problem występuje, tak aby można było właściwie zaplanować badania. Wymaga to wiedzy na temat badanego systemu oraz prawidłowego zrozumienia działania relacji łączących jego elementy.

\section{Metodyka budowy modelu dynamiki systemu zarządzania}

Pierwszym krokiem w budowie modelu dynamiki systemu zarządzania jest wybór przedmiotu badań. Następnie należy wybrać problem o ograniczonym zakresie, tak aby jego obraz był dla nas w pełni zrozumiały, a obszar badań zawsze można poszerzyć. Powinniśmy także poznać historię problemu, aby można go było najkorzystniej opisać, odzwierciedlając jego strukturę.

Sporządzając model dynamiki systemu zarządzania, powinniśmy odpowiedzieć na pytania: co powoduje zmiany w poszczególnych elementach systemu? Co wpływa (oddziałuje) na poszczególne elementy systemu? Jakie połączenia funkcjonują pomiędzy elementami systemu? Odpowiedzi na te pytania są konieczne do prawidłowego zbudowania modelu, aby otrzymane na jego podstawie wyniki badań mogły wiernie odzwierciedlać badany fragment rzeczywistości i nie prowadziły do błędnych wniosków oraz dawały odpowiedzi na pytania: jakie są skutki zmiany danego elementu? Jakie inne elementy się zmieniają? Jak zachowa się system po wprowadzonych zmianach?

Następnie planujemy badania. W tym celu należy wybrać kluczowe zmienne, które dobrze opisują badany problem, oraz zebrać dane ilościowe dotyczące tych zmiennych, a także dane jakościowe, ponieważ dynamika systemów jest metodą, która bazuje zarówno na danych statystycznych, jak i na wiedzy badacza na temat systemu. Po wyznaczeniu zmiennych w następnej kolejności należy wskazać powiązania pomiędzy nimi oraz charakter tych powiązań, odnaleźć istniejące sprzężenia zwrotne oraz przeanalizować rolę, jaką dla działania systemu odgrywa czas, w szczególności, czy istnieją w systemie opóźnienia, które mogą powodować ujawnienie się pełnych efektów działań dopiero po pewnym czasie. W tym momencie można już rozwinąc hipotezę wyjaśniającą przyczynę powstania problemu. Na tej podstawie budujemy myślowy model systemu, który jest diagramem przyczynowo-skutkowym.

Kolejnym krokiem w stosowaniu metody dynamiki systemów jest budowa komputerowego modelu systemu, w którym problem wystąpił; budując model należy pamiętać o celu jego budowy, tak aby zawierał on wszystkie składniki mające związek z rozwiązywanym problemem. Formalny model systemu budujemy na podstawie skonstruowanego wcześniej diagramu przyczynowo-skutkowego. W modelach budowanych przy wykorzystaniu oprogramowania z dziedziny systemów, informacje o systemie wykorzystywane są inaczej niż w innych metodach budowy modeli systemów i procesów społecznych. Właśnie na tym etapie pracy potrzebne są dane jakościowe na temat systemu; wiedza na temat budowy systemu pozwala uwzględnić przy budowie modelu systemu wszystkie formalne i nieformalne powiązania i wpływy występujące 
w systemie, dzięki czemu wyniki późniejszych symulacji zachowania systemu będą bardziej miarodajne oraz zgodne z rzeczywistością (Forrester 1961; Grudzewski 1985; Penc 2000; Śliwa 2001; Tarajkowski 2008).

Gotowy model systemu można symulować, wykorzystując do tego zgromadzone wcześniej dane ilościowe dotyczące elementów systemu. Do budowy i symulacji modelu można wykorzystać stworzone specjalnie do tego celu programy komputerowe, takie jak: Venism firmy Ventana Systems Inc. czy iThink firmy High Performance Systems, albo najstarszy program Dynamo, opracowany przez Jacka Pugh z MIT, lub PowerSim dla gier symulacyjnych służących edukacji. Programy te są narzędziami pozwalającymi w prosty sposób zbudować model systemu oraz przeprowadzić jego symulację. Budowa modelu systemu przy użyciu programu komputerowego polega na graficznym odzwierciedleniu struktury systemu przez system znaków i symboli oraz na uwzględnieniu w nim wszystkich występujących w modelu wpływów (zmiennych) i wzajemnego oddziaływania pomiędzy jego elementami.

Następnym krokiem jest testowanie modelu oraz eksperymentowanie z modelem. Jego celem jest sprawdzenie poprawności działania modelu oraz wprowadzenie niezbędnych poprawek. Należy sprawdzić, czy model zachowuje się zgodnie z modelowaną rzeczywistością, chociaż na tym etapie możemy również odkryć, że zachowanie się systemu było spowodowane zupełnie innymi czynnikami, niż zakładaliśmy. Jeżeli nasz model działa poprawnie, można przystąpić do sprawdzenia hipotezy badawczej oraz alternatywnych sposobów działania czy zachowania się badanego systemu, a także kto może usunąć bądź złagodzić powstały problem, albo wskazać jego rozwiązanie (Grudzewski 1985; Roberts 1964; Rue, Holland 1986; Żukowski 1990; 2011).

Symulacja modelu pozwala nie tylko sprawdzić, jak system zachowa się w przyszłości, ale również umożliwia cofnięcie się w czasie i dotarcie do momentu powstania problemu oraz znalezienie jego przyczyny (przyczyn), tym samym umożliwiając jej (ich) wyeliminowanie w przyszłości. W dłuższym czasie praca $\mathrm{z}$ wykorzystaniem metody dynamiki systemów przy badaniu modelu pozwala na zrozumienie przyczyn pojawiania się problemów, przewidywanie ich i łagodzenie ujemnych skutków zanim jeszcze one powstaną. Jednak należy pamiętać, żeby aby metoda dynamiki systemów była skuteczna w praktyce, najważniejsza jest zmiana sposobu myślenia i patrzenia na generowane problemy przez pryzmat systemu (jego struktury i oddziaływania), w którym występują.

\section{Procedura budowy modelu zarządzania}

Procedura budowy modelu zarządzania organizacją gospodarczą na podstawie metodologii dynamiki systemów opracowanej przez J.W. Forrestera powinna przebiegać według następującej kolejności:

1. Określenie modelowanego problemu (wybór granicy, ograniczeń) (ang. Problem articulation - boundary selection):

1.1. Wybór tematu: Co jest problemem? Dlaczego to jest problemem? (ang. Theme selection: What is the problem? Why is it a problem?),

1.2. Kluczowe zmienne: Określić jakie są kluczowe zmienne i jakie koncepcje należy rozważyć? (ang. Key variables: What are the key variables and concepts we must consider?),

1.3. Horyzont czasowy: W jak odległej przyszłości należy problem rozważać? Jakie w przeszłości były przyczyny powstania problemu? (ang. Time horizont: How far in the future should we consider? Past needs the roots of the problem?), 
1.4. Określenie dynamiki problemu (opis właściwości problemu i zmienności): obecne i przyszłe jego zachowania (ang. Dynamic problem definition/reference modes for problem and variables/present and future behavior);

2. Sformułowanie hipotez dynamiki (ang. Formulation of dynamic hipothesis):

2.1. Generowanie warunków początkowych hipotez: Jakie są aktualne teorie problematyki zachowania się (obiektu) (ang. Initial hypothesis generation: What are current theories of the problematic behavior?),

2.2. Wewnętrzna koncentracja: Hipotezy dynamiki wyjaśniające dynamiczność (dynamikę) jako wewnętrzne konsekwencje struktury sprzężenia zwrotnego (ang. Endogenous focus: dynamic hypothesis explaining dynamics as endogenous consequences of the feedback structure),

2.3. Sporządzanie map: rozwój map wstępnej struktury bazującej na wewnętrznych hipotezach/strukturze wykorzystując takie narzędzia jak: diagramy modeli granicznych, diagramy subsystemów, diagramy pętli przyczynowych, mapy zapasów i przepływów, diagramy struktury polityki (ang. Mapping: Develop maps of casual structure based on initial hypothesis/structure using tools such as: model boundary diagrams, subsystems diagrams, casual loop diagrams, stocks and flaw maps, policy structure diagrams);

3. Opracowanie symulacyjnego modelu (ang. Formulation of a simulation model):

3.1. Specyfikacja (dokładne określenie) struktury, reguł decyzyjnych (ang. Specyfication of structure, decysion rules),

3.2. Szacowanie (estymacja) parametrów, relacji zachowań i warunków początkowych (inicjacja) (ang. Estimation of parameters, behavioral relationships and initial),

3.3. Testy zgodności z zamierzeniem (celem) i granicą (modelu) (ang. Tests for consistency with the purpose and boundary);

4. Testowanie modelu (ang. Testing of a model):

4.1. Porównanie z wskaźnikami odniesienia (oceny): Czy model odtwarza problem behawioralny (zachowania) adekwatnie do twojego zamierzenia? (ang. Comprison to reference models: Does the model reproducer the problem behavior adequately for your purpose?),

4.2. Niezawodność w ekstremalnych warunkach: Czy model zachowuje się realistycznie w warunkach ekstremalnych? (ang. Robustnes under extreme conditions: Does the model behave realistically when stressell by extreme conditions?),

4.3. Wrażliwość: Jak zachowa się model przy niepewności parametrów, warunków początkowych, granicy modelu i agregacji? (ang. Sensitivity: How does the model behave given uncertainly in parameters, initial conditions, model boundary, and aggregation?);

5. Planowanie polityki i jej zmiany (ewolucji) (ang. Policy desing and evolution):

5.1. Scenariusz specyfikacji (dokładnego określenia): Jakie w otoczeniu mogą zaistnieć warunki? (ang. Scenarios specifikation: What environmental conditions might arice?),

5.2. Planowanie polityki: Jakie nowe reguły decyzyjne, strategie i struktury mogą być wypróbowane (zastosowane) w realnej rzeczywistości? Jak mogą one być reprezentowane (przedstawione) w modelu? (ang. Policy design: What new decision rules, strategies and structures might be tired in the real world? How can they be represented in the model?),

5.3. Analizy według schematu: „Co, jeśli...?” Jakie są efekty polityk? (ang. ,, What if...?” analysis, What are the effekts of the politycies?), 
5.4. Analizy wrażliwości: Jak mocne (niezawodne) są rekomendacje polityki przy różnorodności scenariuszów i istniejących niepewnościach? (ang. Sensitivity analysis: How robust are the policy recommendations under different scenarios and given uncertainties?),

5.5. Oddziaływania (interakcje) polityk: Czy zachodzą interakcje między politykami? Czy istnieją synergie (efekty synergii) albo odpowiedzi kompensatorów (wymuszeń)? (ang. Interactions of policies:Do the policies interact? Are there synergies or compensatory responses?).

\section{Budowa modelu dynamiki systemu zarządzania organizacją gospodarczą}

\section{Rozważania wstepne}

Sprawne i efektywne zarządzanie organizacją gospodarczą w warunkach rynkowych wymaga analizy dynamiki systemu zarządzania. Analiza taka stanowi podstawę integracji takich obszarów działalności, jak: rynek, zaopatrzenie, produkcja, dystrybucja, inwestycje, prace badawcze i rozwojowe oraz inne zagadnienia. W miarę kompleksowe podejście do rozpatrywanego problemu wymaga skupienia uwagi na tych składnikach i współzależnościach, które są istotne dla pożądanej właściwości systemu. Podstawowymi elementami takiej działalności są: poszukiwanie analogii, budowa modeli oraz symulacja. Rozważając bowiem jakikolwiek konkretny system, człowiek dąży w istocie do stworzenia w swym umyśle modelu wyjaśniającego zachowanie się obserwowanego systemu (Ansoff 1989; Forrester 1961; 1978; Senge 2008; Żukowski 2011).

Systemy konkretne bywają często bardzo złożone i wówczas trudno jest określić ich rzeczywistą strukturę i właściwości. Staramy się je wtedy wytłumaczyć na drodze analogii między jakimś systemem, który znamy, a systemem badanym. Istotą analogii są relacje równoważności między dwoma systemami. Gdy równoważność ta obejmuje pewien zbiór elementów i czynników istotnych dla interesujących właściwości wyjaśnianego systemu, to mówi się o dobrej analogii, w przeciwnym zaś przypadku - o złej lub pozornej. Ocena czy rozpatrywana analogia jest dobra czy też nie, nie jest sprawą ani prostą, ani łatwą, szczególnie przy bardziej złożonych systemach, a akceptacja niewłaściwej jest często kosztowna. Jedną z metod eliminowania niewłaściwych analogii jest zdobywanie wiedzy o nich na drodze symulacji. Narzędziem umożliwiającym symulację są modele, które powinny odwzorowywać interesujące zależności i właściwości systemu w stopniu wystarczającym dla założonego zakresu badań. Jednocześnie konstrukcja modelu powinna pozwalać na przeprowadzenie badań z możliwością ich powtórzenia dla różnych warunków pracy organizacji gospodarczej (Forrester 1968; Roberts 1964).

Analiza dynamiki systemu zarządzania, według J.W. Forrestera, jest metodą badań charakterystyk informacyjnych sprzężeń zwrotnych w działaniu organizacji gospodarczej. Służy ona poznaniu, jaka jest interakcja struktury organizacyjnej na wzmocnienia (w zakresie wytycznych działania) i opóźnienia (w zakresie decyzji i współdziałania), od których wzajemnego oddziaływania zależna jest sprawność i efektywność pracy całej organizacji. Analizuje się tu głównie współzależności i interakcje (oddziaływania) między strumieniami: materiałów, zamówień, zleceń, produkcji, wyposażenia, personelu, pieniędzy i innych wielkości na różnych poziomach i w różnej skali zarządzania.

Celem podstawowym matematyczno-ekonomicznego opisu dynamiki systemu zarządzania organizacją gospodarczą, w ujęciu modelowym, jest zobrazowanie metodyki i cech budowy tego typu modeli na podstawie metodologii dynamiki systemów J.W. Forrestera. Reprezentuje 
on w sposób uproszczony dowolnie pomyślaną organizację gospodarczą (produkcyjną). Główną uwagę zwróci się na analizę przyczyn fluktuacji zachodzących procesów (określonych wielkości) obserwowanych przy skokowych zmianach, w warunkach rynkowych, potoku zamówień na produkty finalne. Analiza taka powinna eksperymentalnie ujawniać przybliżone ilościowe współzależności między strukturą organizacyjną i wytycznymi działania, a stabilnością pracy organizacji gospodarczej. Wyniki symulacji na modelu wskażą na pewne właściwości dynamiki zachowania się organizacji gospodarczej (kształtowania się charakterystycznych i nas interesujących wielkości) w trakcie jej pracy (Grudzewski 1985; Forrester1971; 1990; Porter 1985; Rue, Holland 1986; Śliwa 2001; Tarajkowski 2008; Żukowski 2001).

\section{Ogólny opis modelu, wytyczne działania}

W opisie symboliczno-analogowym modelu ogólnie pomyślanej organizacji gospodarczej (ryc. 1) wyróżniono pięć kluczowych działów i wydziałów, które reprezentowane są przez następujące wielkości (ich poziomy): $D S$ - portfel zamówień (liczba przyjętych zamówień na produkty finalne), $D Z$ - liczba zleceń zakupu materiałów akumulowana w dziale zaopatrzenia, $M M-$ zawartość surowców, materiałów i półfabrykatów w magazynie materiałów, $P R$ - wielkość produkcji wydziału (zakładu) produkcyjnego i $M P$ - wielkość zapasów produkcji finalnej w magazynie. Sformułowano też niezbędne wytyczne (reguły) działania. Wytyczne te dla personelu kierowniczego są następujące:

1. wielkość produkcji, a ściślej wielkość zleceń produkcyjnych $(Z P R)$ powinna być taka, aby zapewnić $k$-krotnie wyższy poziom produkcji finalnej w magazynie produktów $(M P)$ w stosunku do uśrednionej liczby przychodzących z rynku zamówień $(Z S)$ na produkty finalne (np. współczynnik wzmocnienia $\mathrm{k}=3$ tygodnie). Warunek ten jest spełniany przez przesyłanie do wydziału (zakładu) produkcyjnego $(P R)$ zleceń produkcyjnych $(Z P R)$, stanowiących sumę złożoną z uśrednionej liczby przyjmowanych zamówień $(Z S)$ na produkty finalne i różnicy $\left(\mathrm{S}_{1}\right)$ między pożądaną zawartością produktów finalnych w magazynie produktów a jego rzeczywistym stanem. Wielkość $Z P R$ wyznaczymy z formuły:

$Z P R=Z S+S_{1}$,

gdzie:

$Z_{S}-$ uśredniona liczba przyjmowanych zamówien,

$S_{1}$ - zmienna pomocnicza.

Pożądana zawartość produktów finalnych w magazynie produktów $(k \cdot Z S)$ to iloczyn uśrednionej wielkości zamówień produktów finalnych $(Z S)$ i współczynnika wzmocnienia $(k)$. Współczynnik $k$ określa liczbę tygodni, w ciągu których pożądana zawartość produktów finalnych w magazynie produktów $(M P)$ byłaby wystarczająca dla ich wysyłki odbiorcom $\mathrm{z}$ prędkością równą średniej prędkości napływających z rynku zamówień. Zmienną pomocniczą $S_{1}$ zatem obliczy się ze wzoru:

$S_{1}=k \cdot Z S-M P$,

gdzie:

$k$ - współczynnik wzmocnienia,

MP - faktyczna zawartość produktów finalnych w magazynie produktów;

2. w wypadku, gdy poziom materiałów i półfabrykatów w magazynie materiałów $(M M)$ zabezpieczający produkcję spada poniżej poziomu określonego przez portfel przyjętych zamówień $(D S)$, należy wstrzymać przyjmowanie nowych zamówień na produkty finalne $(Z D S)$ - wykorzystuje się tu zmienną pomocniczą $S_{2}$ (ryc. 1); 
3. podobnie jak w wytycznej 2, gdy zawartość materiałów (półfabrykatów) w magazynie materiałów $(M M)$ spadnie poniżej pewnej, z góry określonej wartości (Min), należy wstrzymać przesyłanie zleceń produkcyjnych (ZZR) do wydziału (zakładu) produkcyjnego $(P R)$ - wykorzystuje się tu z kolei zmienną pomocniczą $S_{3}[8,10,11]$ (ryc. 1). Zmienna pomocnicza $S_{3}$ wyraża różnicę między aktualną zawartością materiałów i półfabrykatów w magazynie materiałów $(M M)$ a pewnym jego zapasem minimalnym (Min). Zmienną pomocniczą $S_{3}$ oblicza się ze wzoru:

$S_{3}=M M-$ Min

4. wielkość strumienia zleceń na zakup materiałów i półfabrykatów (ZDZ), wysyłanych do działu zaopatrzenia $(D Z)$, musi być równa wielkości strumienia zamówień z rynku sprzedaży na produkty finalne $(R K)$, napływających do działu sprzedaży;

5. w przepustowości informacyjnej prac biurowych, czasy przejścia zostały odpowiednio oznaczone: $T Z S$ - czas przejścia niezbędny do uśredniania zamówień na produkty finalne, $T D Z$ - czas przejścia niezbędny do zakupu materiałów, $T P R$ - czas przejścia niezbędny do produkcji, $T D S$ - czas przejścia niezbędny do dystrybucji oraz TMP - czas przejścia niezbędny dla realizacji wytycznej 1 .

Ryc. 1. Symboliczno-analogowy model zarządzania organizacją gospodarczą

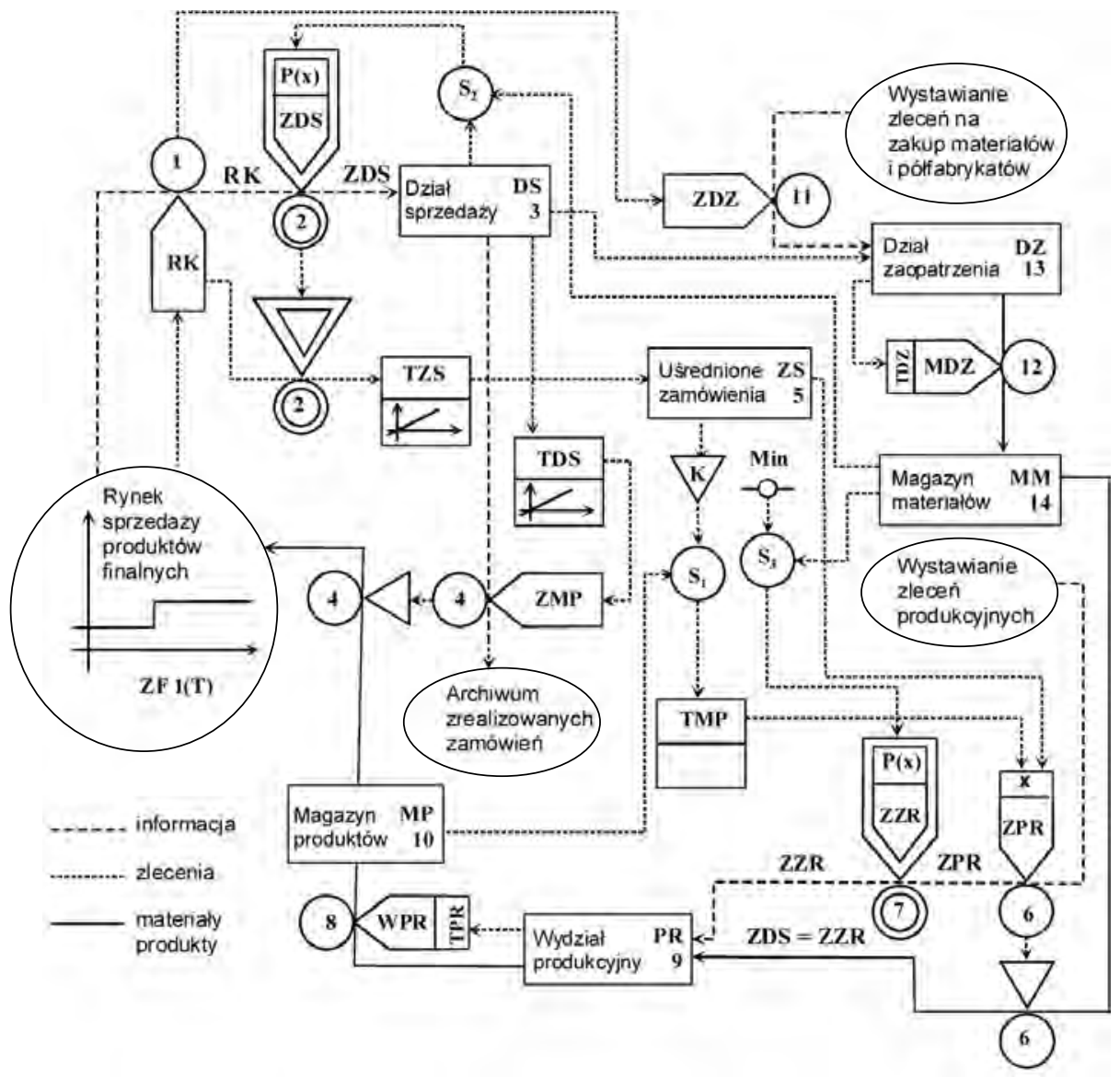

Źródło: opracowanie własne. 


\section{Matematyczny opis dynamiki systemu zarzadzania}

$\mathrm{Z}$ rynku sprzedaży produktów finalnych płyną dwa strumienie (ryc. 1); jeden z nich niesie zamówienia na produkty finalne, drugi zaś - informacje o ich wielkości.

Na pierwszym stanowisku decyzyjnym, oznaczonym na ryc. 1 przez poziom RK, opisuje się wielkość napływających z rynku zamówień na produkty finalne. Wielkość RK ma charakter skokowy i wyliczyć ją można ze wzoru:

$R K=R K_{0}+Z F \cdot 1(T)$,

gdzie:

$R K_{0}$ - początkowa liczba zamówień na produkty finalne,

$Z F$ - liczba napływających do organizacji z rynku zamówień na produkty finalne.

Drugie stanowisko decyzyjne, poziom $Z D S$, reguluje dopływ zamówień na produkty finalne, które można przyjąć ze względu na istniejące zabezpieczenie materiałowe (realizacja wytycznej 2 z wykorzystaniem zmiennej S2) i jednocześnie koryguje informację o wielkości strumienia tych zamówień przez skierowanie informacji do „uśredniania” zamówień (ZS). Działanie drugiego stanowiska decyzyjnego określa funkcja $F^{*}$ w postaci:

$F^{*}=\left\{\begin{array}{l}1, \text { gdy } M M \geq D S \\ 0, \text { gdy } M M<D S\end{array}\right.$

Wielkość $Z D S$ wyliczymy z zależności:

$Z D S=F^{*} \cdot R K$

Stanowisko decyzyjne 3, poziom $D S$ (portfel zamówień), określa liczbę przyjętych zamówień na produkty finalne. Wielkość $D S$ obliczymy ze wzoru:

$D S=D S_{0}+T(Z D S-Z M P)$,

gdzie:

$D S_{0}$ - poprzednia liczba zamówień na produkty finalne,

$T$ - przedział czasu,

$Z D S$ - wielkość strumienia przyjętych zamówień na produkty finalne,

$Z M P$ - wielkość strumienia zrealizowanych zamówień na produkty finalne.

Stanowisko decyzyjne 4, poziom $Z M P$, reguluje:

- wielkość wysyłki zamówionych produktów finalnych z magazynu $(M P)$,

- wielkość odpowiadającego tej wysyłce odpływu załatwionych zamówień z portfela zamówień na produkty finalne do archiwum.

Wielkość ZMP obliczymy z zależności:

$Z M P=D S / T D S$,

gdzie:

$D S$ - portfel przyjętych zamówień na produkty finalne,

$T D S$ - czas przejścia realizacji zamówienia na produkt finalny (jest wartością stałą, np. tydzień).

Stanowisko decyzyjne 5, poziom ZS (uśrednianie napływających zamówień na produkty finalne), reprezentuje średnią wielkość strumienia napływających z rynku zamówień na produkty finalne RK (z uwzględnieniem korekcyjnego działania 2 stanowiska decyzyjnego - ZDZ). Wielkość $Z S$ wyliczymy z formuły:

$Z S=Z S_{0}+T\left(Z D S-Z S_{0}\right)$,

gdzie:

$Z S_{0}$ - poprzednia liczba uśrednienia zamówień na produkty finalne,

$T$ - przedział czasu,

$Z D S$ - wielkość strumienia przyjętych zamówień na produkty finalne. 
Stanowisko decyzyjne 6, poziom $Z P R$, reguluje (wykorzystując zmienną pomocniczą $S_{1}$, zgodnie z wytyczną 1):

- wielkość przepływu zleceń produkcyjnych przesyłanych do wydziału (zakładu) produkcyjnego,

- wielkość strumienia materiałów i półfabrykatów przesyłanych do produkcji (PR), a pobieranych z magazynu materiałów (MM).

Wielkość strumienia zleceń produkcyjnych $(Z P R)$ jest równa sumie średniej wielkości napływających zamówień na produkty finalne $(Z S)$ oraz poprawce wyrażonej ilorazem wielkości pomocniczej $S_{1}$ i czasu przejścia $T P R$. Wielkość $Z P R$ wyliczymy ze wzoru:

$Z P R=Z S+S_{1} / T P R$

Stanowisko decyzyjne 7, poziom $Z Z R$, zapewnia realizację 3 wytycznej działania odcinając dopływ zleceń produkcyjnych przesyłanych do wydziału produkcyjnego, gdy stan materiałów lub półfabrykatów w magazynie materiałów $(M M)$ osiągnie zapas minimalny (Min). Działanie stanowiska 7 określa funkcja $P^{*}$ w postaci:

$$
P^{*}=\left\{\begin{array}{l}
1, \text { gdy } S_{3} \geq 0 \\
0, \text { gdy } S_{3}<0
\end{array}\right.
$$

Wielkość $Z Z R$ zaś określi się z zależności:

$Z Z R=P^{*} \cdot Z P R$

Stanowisko decyzyjne 8 , poziom $W P R$, stanowi element przepustowości wykładniczej pierwszego rzędu i określa czas przejścia potrzebny na produkcję. Przyjmuje się, że czas ten $(T P R)$ jest wartością stałą (np. 2 tygodnie), zaś elementem akumulującym przepustowość jest zawartość portfela zleceń produkcyjnych $(P R)$. Wielkość WPR obliczymy z zależności:

$W P R=P R / T P R$

Stanowisko decyzyjne 9, poziom $P R$, określa aktualną wielkość portfela zleceń produkcyjnych. Wielkość ta jest równa sumie poprzedniej wielkości zleceń produkcyjnych $\left(P R_{0}\right)$ i akumulowanej różnicy między napływem nowych zleceń produkcyjnych do wydziału $(Z Z R)$ a ich odpływem, równoważnym wielkości produkcji (WPR).

$P R=P R_{0}+T(Z Z R-W P R)$

Stanowisko decyzyjne 10, poziom $M P$, reguluje zawartość magazynu produktów finalnych; stan magazynu tych produktów jest zasilany strumieniem produkcji (WPR) z wydziału (zakła$\mathrm{du}$ ) produkcyjnego, zaś wyjściem jest strumień produktów finalnych $(Z M P)$ wysyłanych przez dział sprzedaży, zgodnie z zamówieniami klientów. Różnica między tymi strumieniami jest akumulowana w magazynie produktów finalnych $(M P)$. Wielkość $M P$ określi się ze wzoru:

$M P=M P_{0}+T(W P R-Z M P)$, gdzie:

$M P_{0}$ - poprzednia zawartość magazynu produktów finalnych.

Stanowisko decyzyjne 11, poziom $Z D Z$, określa wielkość strumienia zamówień (zleceń zakupu) materiałów i półfabrykatów przez dział zaopatrzenia i, zgodnie z wytyczną działania 4 równa się strumieniowi zamówień na produkty finalne $(R K)$.

Wielkość $Z D Z$ równa jest więc $R K$ :

$Z D Z=R K$ 
Stanowisko decyzyjne 12, poziom $M D Z$, reprezentuje strumień materiałów i półfabrykatów zakupionych i dostarczonych do magazynu materiałów $(M M)$ przez dział zaopatrzenia. Wielkość tego strumienia jest regulowana na podstawie liczby zleceń na zakup materiałów i półfabrykatów zakumulowanej w zaopatrzeniu $(D Z)$. Wielkość $M D Z$ określimy z zależności:

$M D Z=D Z / T D Z$,

gdzie:

$T D Z$ - czas przejścia potrzebny na zakup materiałów i półfabrykatów, przyjmuje się go jako wielkość stałą (np. 2 tygodnie).

Stanowisko decyzyjne 13, poziom $D Z$, akumuluje różnicę między napływającym strumieniem zleceń zakupu materiałów i półfabrykatów $(Z D Z)$ a strumieniem ich odpływu, tj. realizacji. Ta ostatnia wielkość jest równoważna strumieniowi zakupionych materiałów i półfabrykatów przez zaopatrzenie $(M D Z)$ i przekazanych do magazynu materiałów $(M M)$. Wielkość $D Z$ wyliczymy ze wzoru:

$D Z=D Z_{0}+T(Z D Z-M D Z)$,

gdzie:

$D Z_{0}$ - poprzednia liczba zleceń zakupu materiałów i półfabrykatów.

Stanowisko decyzyjne 14, poziom $M M$, akumuluje różnicę między strumieniem zakupionych materiałów i półfabrykatów $(M D Z)$ a strumieniem ich odpływu do produkcji $(Z P R)$. Wielkość $M M$ określimy ze wzoru:

$M M=M M_{0}+T(M D Z-Z P R)$,

gdzie:

$M M_{0}$ - początkowy poziom materiałów i półfabrykatów w magazynie.

\section{Interpretacja wyników symulacji}

W symulacji, wykorzystując zbudowany model, zbadano zachowanie się organizacji gospodarczej w wypadku, gdy zamówienie na produkty finalne wzrasta o $Z F=40$ jednostek/tydzień przy początkowym poziomie materiałów w magazynie $M M_{0}=270$ jednostek (ryc. 2). Z wyniku symulacji przedstawionej na rycinie 2 wynika, że przy skokowym wzroście zamówienia na produkty finalne o $Z F=40$ jednostek/tydzień zaburzenia przejściowe w pracy opisanej organizacji gospodarczej, wyrażające się wahaniem poziomu produkcji $(P R)$ oraz przepływu zleceń i materiałów na produkcję $(Z P R)$, są obserwowane jeszcze w 35 tygodniu pracy, przy czym rozpiętość wahań sięga około $10 \%$ średniej ich wartości. Wykres ten wykazuje ponadto przyczynę nadmiernego wydłużania się okresu zaburzeń przejściowych w pracy badanej organizacji gospodarczej.

Jak widać na rycinie 2, krzywe wielkości $M M$ i $D S$ przenikają się, co - zgodnie z wytycznymi działania 2 i 3 - powoduje okresowe wstrzymanie przyjmowania zamówień na produkty finalne. Efekt ten jest równoważny rynkowym zmianom (wahaniom) wielkości zamówień na produkty finalne i wprowadza dodatkowe zaburzenia w pracy organizacji gospodarczej. Jednak zaburzenia te - wbrew pozorom - nie są wywołane, jak pokazują wyniki obliczeń (symulacji), przyczynami zewnętrznymi, pochodzącymi z rynku, lecz tylko okolicznościami wewnętrznymi zależnymi głównie od wielkości zamówienia na produkty finalne $(Z F)$ i zapasu początkowego materiałów i półfabrykatów w magazynie $\left(M M_{0}\right)$. 
Ryc. 2. Wyniki symulacji w przypadku wzrostu zamówienia o 40 jednostek/tydzień przy początkowym poziomie materiałów w magazynie 270 jednostek

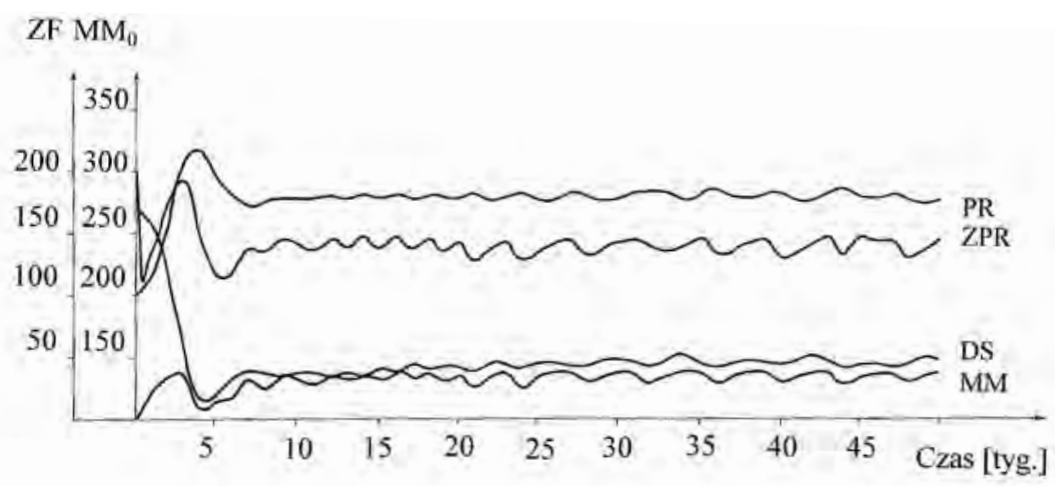

Źródło: opracowanie własne.

Opracowany model dynamiki systemu zarządzania organizacją gospodarczą został zweryfikowany przez porównanie uzyskanych wielkości modelowych z danymi rzeczywistymi pewnego zakładu meblarskiego. Wyniki symulacji na modelu pokazują, że przy skokowym zamówieniu na produkty finalne obserwuje się przejściowe zaburzenia w pracy zakładu, wyrażające się przede wszystkim zmianami wielkości produkcji i poziomu przepływu materiałów do produkcji. Zaburzenia te zanikają w różnych okresach. Długość okresu zależy od wielkości zamówienia na produkty finalne $(Z F)$ i zapasu początkowego materiałów i półfabrykatów w magazynie $\left(M M_{0}\right)$.

Zbudowany model dynamiki systemu zarządzania organizacją ma znaczenie praktyczne, bowiem pozwala przewidzieć ewentualny okres (w tygodniach) zaburzenia w organizacji gospodarczej w przypadku przyjęcia nadesłanej wielkości zamówienia (oferty) na produkty finalne, znając wielkość początkową zapasów materiałów i półfabrykatów w magazynie. 


\section{Literatura}

1. Agor W., 1984, Intuitive Management: Integrating Left and Right Brain Management Skills, Prentic-Hall, Englewood Cliffs, New York.

2. Ansoff H.I., 1989, Zarzadzanie strategiczne, PWE, Warszawa.

3. Argyris C., 1982, Reasoning, Learning and Action: Individual and Organizational, Jossey-Bass, San Francisco.

4. Argyris C., 1985, Strategy, Change, and Defensive, Routines Pitman, Boston, Mass.

5. Checkland P., 1981, Systems Thinking, Systems Practice, John Wiley, New York.

6. Forrester J.W., 1961, Industrial Dynamics, MIT Press, Cambridge, Mass.

7. Forrester J.W., 1968, Principles of Systems, MIT Pres, Cambridge, Mass.

8. Forrester J.W., 1971, Word Dynamics, MIT Pres, Cambridge, Mass.

9. Forrester J.W., 1978, Mirowaja dinamika, Nauka, Moskwa.

10. Forrester J.W., 1990, System Dynamics as a Foundation for Pre-College Education, Memorandum D-4133, 14 pages, System Dynamics Group, Sloan School, Massachusetts Institute of Technology.

11. Grudzewski W.M. (red.), 1985, Badania operacyjne w organizacji i zarzadzaniu, PWE, Warszawa.

12. MacDonald F., 1992, Albert Einstein, Published by Exley Publications Ltd, 16 Chalk Hill.

13. Penc J., 2000, Kreatywne kierowanie, AW Placet, Warszawa.

14. Porter M.E., 1985, Competitive Advantage, MIT Press, New York.

15. Richardson G.P., 1991, Feedback Thought in Social Science and Systems Theory, University of Pennsylvania Press, Philadelphia.

16. Roberts E.B., 1964, Dynamics of Researh and Development, Harpertand Row, New York.

17. Rue L.W., Holland Ph.G., 1986, Strategic Management: Concepts and Experiences, McGraw-Hill., New York.

18. Senge P.M., 2008, Piąta dyscyplina, Wolters Kluwer Polska, Kraków.

19. Śliwa K.R., 2001, O organizacjach inteligentnych, Oficyna Wydawnicza WSM SIG, Warszawa.

20. Tarajkowski J., 2008, Elementy dynamiki systemów, Wyd. AE, Poznań.

21. Thompson A.A., Stricland A.J., 1992, Strategy Formulation and Implementation, Richard D. Irwin, Cambridge, Mass.

22. Wagner H.M., 1975, Principles of Operations Research with Applications to Managerial, Prentice-Hall, Englewood Cliff, New Jersey.

23. Żukowski P., 1990, Postrojenije i issliedowanije dinamiczieskoj modieli uprawlenija miebielnym priedprijatijem (sistiemnyj podchod), Archangielsk: Lesnoj Żurnał, 2.

24. Żukowski P., Prusak Z., 1999, Design and analysis of the dynamic management model of a manufacturing company, In: The 15th international conference on production research: Manufacturing for a global market (Ed. M.T. Hillery \& H.J. Lewis), University of Limerick, Limerick (Ireland).

25. Żukowski P., Winnicki K., Grabowiecka R., 2000, The Management model of an Agriculture company, In: Проблемы управления агропромышленным комплексом России (Problemy zarządzania agroprzemystowym kompleksem Rosji), m. III - Теория и практика управления предприятиями АПК,Российская академия сельскохозяйственных наук, Всероссийский научноисследовательский институт экономики сельского хозяйства, Санкт-Петербург.

26. Żukowski P., 2006, Podstawy nauk o zarządzaniu, Oficyna Wydawnicza Politechniki Rzeszowskiej, Rzeszów.

27. Żukowski P., 2011, Projektowanie modelu dynamiki systemu zarzadzania organizacja i jego symulacja (zagadnienia metodologiczne) [w:] Koncepcje, modele, metody i techniki zarzadzania, H. Howaniec, A. Madyda, W. Waszkielewicz (red.), Wyd. ATH, Bielsko-Biała. 


\section{Basis of building management system dynamics model with simulation on economic organization (on the base of methodology J.W. Forrester)}

In the work chapter, after discussing issues related to systems thinking, mental models, system dynamics and procedure of modeling, presents the socio-mathematical description of the dynamics of economic organization management system based on system dynamics methodology developed by Jay W. Forrester, as a creative concept used for researching system thinking. The purpose of this description is to illustrate the methodology and characteristics the construction this type of that models. This description is a simply way represent any economic organization (production), which show the organizational units (departments and production department), the flows of orders, the streams of information about materials and prefabricates, final products and their storage and sales. Built model of system dynamics allow management to analyze the causes of fluctuations In the processes of economic organization changes observed at the urgen changes to take new orders for final products.

The simulation made on the basic experimentally constructed model revealed certain properties characteristic of the dynamic behavior of economic organization (formation of the characteristic and interesting letter size) at its manufacturing operations in case of adoption of new orders for final products. 